\title{
Monitoring of Ammoniacal Nitrogen and Phosphate in the Leachates When Diluted Palm Oil Mill Effluent was Used as a Fertilizer
}

\author{
NURUL IYLIA SALLEH ${ }^{1}$, TZE-PEI PHAN*1, SENG LAU ${ }^{1}$, CHEE-BENG YEOH $^{2} \&$ \\ MENG-GUAN TAY ${ }^{1}$
${ }^{1}$ Faculty of Resource Science and Technology, Universiti Malaysia Sarawak, 94300 Kota Samarahan, Sarawak, Malaysia; ${ }^{2}$ Malaysian Palm Oil Board, Bandar Baru Bangi, 43000
Kajang, Selangor, Malaysia.
*Corresponding author: christina_ptp@hotmail.com \\ Received: 21 March $2019 \quad$ Accepted: 16 May $2019 \quad$ Published: 30 June 2019
}

\begin{abstract}
Palm oil mill effluent (POME) contains a high amount of nutrients and organic matter; therefore, it has been considered as an alternative liquid fertilizer (LF). However, the studies on the reuse of POME as fertilizer have been mostly limited to nutrients absorption but the leachates were neglected. Such approach caused potential impacts on ground water pollution. Thus, this research aimed to compare the leachabilities of ammoniacal nitrogen $\left(\mathrm{NH}_{3}-\mathrm{N}\right)$ and phosphate $\left(\mathrm{PO}_{4}{ }^{3-}\right)$, as well as the growth rates of oil palm seedlings in three different watering conditions. Six oil palm seedlings were watered with either POME, LF or tap water. The leachates from each seedling pot were collected weekly and analyzed for their $\mathrm{NH}_{3}-\mathrm{N}$ and $\mathrm{PO}_{4}{ }^{3-}$ concentrations. The pots which were watered with tap water showed the highest leaching rate of $0.0251 \mathrm{mg} . \mathrm{L}^{-1}$. week ${ }^{-1}$ for $\mathrm{NH}_{3}-\mathrm{N}$ and $0.0392 \mathrm{mg} . \mathrm{L}$ ${ }^{1}$. week ${ }^{-1}$ for $\mathrm{PO}_{4}{ }^{3-}$. The average concentrations of $\mathrm{NH}_{3}-\mathrm{N}$ in the leachates from the POME, $\mathrm{LF}$ and tap water pots were $0.45,0.38$ and $0.36 \mathrm{mg} / \mathrm{L}$, respectively, whereas for $\mathrm{PO}_{4}{ }^{3-}$, the average concentrations were 1.09 (POME), 0.96 (LF) and 0.66 (tap water) $\mathrm{mg} / \mathrm{L}$. The quickest plant growth rates were recorded in tap water $(0.56 \mathrm{~cm} /$ day), followed by LF $(0.51 \mathrm{~cm} /$ day $)$ and POME $(0.42 \mathrm{~cm} /$ day $)$.
\end{abstract}

Keywords: Fertilizer, leachate, nutrient absorption, plant growth, POME

Copyright : This is an open access articledistributed under the terms of the CC-BY-NC-SA(Creative Commons Attribution-NonCommercial-ShareAlike 4.0 International License) which permits unrestricted use, distribution, and reproduction in any medium, for non-commercial purposes, provided the original work of the author(s) is properly cited.

\section{INTRODUCTION}

Palm oil mill effluent (POME) is a brownish liquid waste, produced from palm oil mills particularly in the sterilizer condensate and the oil-sludge clarification processes (Patel, 2015; Liew et al., 2015). This type of wastewater contains a high amount of nutrient (ammoniacal nitrogen $=220 \mathrm{mg} / \mathrm{L})$ and organic matter $(\mathrm{COD}$ value $=\sim 50,000 \mathrm{mg} / \mathrm{L})$, which can cause significant negative impact to the environment (DOE, 1999; Madaki and Lau, 2013; Loh et al., 2013). In addition to the high amount of pollutants, POME is also generated in extremely large volume per day. According to previous reports, an ordinary mill with a daily production of 360 tons of crude palm oil can generate up to 1,260 ton of POME (Ahmad et al., 2005a).
Researchers have published numerous articles on the treatment of POME, including membrane filtration (Ahmad et al., 2005b), oxidation pond (Rupani et al., 2010), coagulation (Norulaini et al., 2001) and advance oxidation processes (Lim et al., 2017). Alternatively, instead of degrading the pollutants in POME, the reuse of POME as a fertilizer has also attracted substantial researches (Onyia et al., 2001; Wu et al., 2009; Ogboi \& Izeke, 2010; Nwoko \& Ogunyemi, 2010; Iwara et al., 2011; Afandi et al., 2016). Despite the positive findings that POME has good fertilizer value, it has not been adopted by oil palm planters. The fear that the applied POME may pollute ground water may have prohibited its application in the field. We reported a leaching study of ammoniacal nitrogen $\left(\mathrm{NH}_{3}-\mathrm{N}\right)$ from different soil mediums that have been watered with POME over seven-days of retention time. 
We found that the amount of $\mathrm{NH}_{3}-\mathrm{N}$ leaching decreased with the increase in the retention time, and importantly that the soil texture is the main factor that influences the leachability of $\mathrm{NH}_{3}-\mathrm{N}$ (Jefferson et al., 2016).

Herein, we extended our previous study by planting six oil palm seedlings in separate pots that have similar soil texture found to have the highest $\mathrm{NH}_{3}-\mathrm{N}$ absorption ability from our previous study. The objectives of this study were (i) to determine and compare the nutrients leached into groundwater from the soil treated with POME and commercially available liquid fertilizer; (ii) to investigate the possibility of POME polluting the ground water by integrating the nutrient concentrations in the leachates; and (iii) to determine the growth of oil palm seedlings under the three different watering conditions.

\section{MATERIALS AND METHODS}

\section{POME Sample}

The POME samples were collected from the palm oil mill located in Bau-Lundu, Sarawak, Malaysia, in October and December 2016. About $15 \mathrm{~L}$ of POME samples were collected from the cooling pond and kept in six polyethylene bottles. The polyethylene bottles were kept in a refrigerator at a temperature of 4 ${ }^{\circ} \mathrm{C}$ before being analysed.

\section{Soil Medium and Soil Analysis}

The soil medium used in this project was bought from Wong Sian Hup Pottery Sdn. Bhd, Kuching, Sarawak, Malaysia. The soil color, $\mathrm{pH}$, texture, soil organic matter (SOM) and moisture (MO) content were analyzed by following the standard methods as stated in the United States Department of Agriculture (USDA, 2014) prior to use as the medium for planting the oil palm seedlings. The soil color was determined by comparing soil samples with the standard soil color chart called Munsell Soil Color Chart, whereas the soil $\mathrm{pH}$ was determined using Mettler Toledo Model $\mathrm{S} 20 \mathrm{pH}$ meter, which has been calibrated in $\mathrm{pH}$ 7 and 4 buffer solutions.

For soil texture analysis, $10.0 \mathrm{~g}$ of $2.0 \mathrm{~mm}$ soil sample and $50 \mathrm{~mL}$ of $6 \%$ of $\mathrm{H}_{2} \mathrm{O}_{2}$ were mixed together in a beaker and left overnight.
Sufficient water was added to maintain the mixture volume at about $300 \mathrm{ml}$ to $400 \mathrm{ml}$. Then, the mixture was stirred and heated at $300{ }^{\circ} \mathrm{C}$ for 2 hours. The mixture was allowed to cool down, and the $\mathrm{pH}$ of the mixture was adjusted to $\mathrm{pH} 3.5$ with $1.0 \mathrm{M} \mathrm{HCl}$ acid. Then, $2 \mathrm{~mL}$ of $1.0 \mathrm{M} \mathrm{NaCl}$ solution was added into the mixture and left overnight to form precipitation of clay particle.

After 24 hours, the water from the mixture was discarded by decantation and another $300 \mathrm{~mL}$ of distilled water was added into the mixture. The $\mathrm{pH}$ of the mixture was again adjusted to $\mathrm{pH} 10.5$ by using $30 \%$ of $\mathrm{NaOH}$ solution. The mixture was transferred to a 11 measuring cylinder and topped up to 11 with distilled water. Meanwhile, two $50 \mathrm{~mL}$ beakers were heated at $105^{\circ} \mathrm{C}$ for 24 hours in an oven and this step was repeated until a constant weight of the beaker was obtained.

After 24 hours, the temperature of the mixture was recorded. The mixture in the measuring cylinder was shaken for 1 minute to leave the settling of the clay suspension. After the settling time (clay fraction: 6 hours $47 \mathrm{~min}$ ), $10 \mathrm{ml}$ of the suspension was pipetted at $10 \mathrm{~cm}$ depth of water and was transferred into one of the $50 \mathrm{ml}$ ovendried beakers. The mixture left in the measuring cylinder was then shaken for another 1 minute to leave the settling of silt and clay suspension. After the settling time (silt + clay fraction: 4 min $4 \mathrm{sec}$ ), $10 \mathrm{ml}$ of water suspension was pipetted at also a $10 \mathrm{~cm}$ depth of water and then was transferred into another $50 \mathrm{ml}$ oven-dried beaker. Both samples were oven-dried for 24 hours at $105{ }^{\circ} \mathrm{C}$. After 24 hours, both beakers were allowed to cool down and the reading of the air dried beakers were recorded.

The percentages of silt, clay and sand were determined based on the difference in between fractions obtained at specific time intervals (Jefferson et al., 2016). The soil texture analysis was conducted in triplicates and the calculation of the silt, clay and sand percentages are as shown in Eq. 1-3.

$$
\begin{array}{ll}
\text { Clay }(\%)=\left(\mathrm{X}_{2}-\mathrm{X}_{1}\right) \times 100 \times 10 & \text { Eq. } 1 \\
\text { Silt }(\%)=\left[\left(\mathrm{Y}_{2}-\mathrm{Y}_{1}\right)-\left(\mathrm{X}_{2}-\mathrm{X}_{1}\right)\right] \times 100 \times 10 & \text { Eq. } 2 \\
\text { Sand }(\%)=100-(\text { Clay } \%+\text { Silt } \%+\mathrm{SOM}+\mathrm{MO}) & \text { Eq. } 3
\end{array}
$$

Where, $\mathrm{X}_{1}=$ weight of beaker

$\mathrm{X}_{2}=$ weight of clay fraction

$\mathrm{Y}_{1}=$ weight of beaker

$\mathrm{Y}_{2}=$ weight of clay and silt fraction

$\mathrm{SOM}=$ soil organic matter

$\mathrm{MO}=$ moisture content 
Meanwhile, the SOM and MO analyses were adapted based on the loss on ignition (USDA, 2014). Firstly, a crucible was oven-dried for 24 hours at $105{ }^{\circ} \mathrm{C}$. After that, it was allowed to cool down to room temperature before the weight of the crucible was recorded. This process was repeated several times until a constant reading of the oven-dried crucible.

Next, $3.0 \mathrm{~g}$ of $0.30 \mathrm{~mm}$ of soil sample was placed in the crucible and then heated in an oven at $105^{\circ} \mathrm{C}$ for 24 hours. Again, the crucible was allowed to cool down to room temperature before the weight of the oven-dried sample was taken. Then, the oven-dried sample was heated in a furnace for 8 hours at $550{ }^{\circ} \mathrm{C}$. The crucible was then allowed to cool down again and the final weight of the furnace-dried sample was taken (USDA, 2014). The SOM and MO analyses were repeated three time and the calculation are shown in Eq. 4-6.

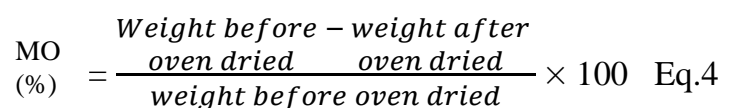

$\begin{aligned} & \text { Mineral } \\ & \text { content }(\%)\end{aligned}=\frac{\text { Weight after furnace }}{\text { Weight aftern oven }} \times 100 \quad$ Eq. 5

$\operatorname{SOM}(\%)=100-$ mineral content

Eq. 6

\section{The Design of the Pilot Study: Oil Palm Seedling, Leachate Collection and Analysis}

Six oil palm seedlings were bought from the Asajaya Nursery Sdn. Bhd., Samarahan, Sarawak, Malaysia. The oil palm seedlings were planted in 181 plastic pots and two of each seedling were then watered with either POME (Figure 1), LF or tap water (control). The LF used in this study was formulated with the $\mathrm{N}: \mathrm{P}: \mathrm{K}$ ratio of $15: 15: 15$ due to the equivalent ratio of $\mathrm{N}$ and $\mathrm{P}$ in the content.

Each watering consisted of approximately 1 1 and it was performed twice a day in the morning (about 0800-1000 hrs) and afternoon (about 1500-1700 hrs). On rainy days, no watering was done. For POME, prior to watering the pot, the initial concentration of
$\mathrm{NH}_{3}-\mathrm{N}$ was adjusted to $0.60 \mathrm{mg} / \mathrm{l}$ by dilution with tap water, whereas for LF, the initial concentrations of $\mathrm{NH}_{3}-\mathrm{N}$ and $\mathrm{PO}_{4}{ }^{3-}$ were 0.60 $\mathrm{mg} / \mathrm{l}$, which can be prepared by dissolving about $0.004 \mathrm{~g}$ of fertilizer in 11 of distilled water. A plastic container was placed under each plastic pot to collect the leachate. The leachates were collected weekly, especially the day after rain. If there was no rain in a particular week, no leachate sample was collected. The concentrations of $\mathrm{NH}_{3}-\mathrm{N}$ and $\mathrm{PO}_{4}{ }^{3-}$ in POME were analysed based on $\mathrm{HACH}$ methods namely $\mathrm{HACH} 8155$ for $\mathrm{NH}_{3}-\mathrm{N}$ and $\mathrm{HACH} 8048$ for $\mathrm{PO}_{4}{ }^{3-}$ with a $\mathrm{HACH}$ calorimeter DR890.

Lastly, the initial heights of the seedlings were recorded and the heights of the oil palm seedlings measured and recorded every month

\section{Linear Regression Calculation}

The concentrations of these two parameters were plotted in a scatter graph using Microsoft Excel. A linear regression formula, $y=\mathrm{m} x+\mathrm{C}$, was added to the scatter plots for each oil palm seedling pot and the leaching rate of the respective nutrient was obtained from the slope of the linear line, which is the $\mathrm{m}$ value. The higher the $m$ value, the more nutrients are being leached out and the higher possibility of polluting the ground water.

\section{Absorption Ability Calculation}

The absorption abilities (\%) of $\mathrm{NH}_{3}-\mathrm{N}$ and $\mathrm{PO}_{4}{ }^{3-}$ were calculated by using the nutrients concentration from the plants watered with tap water only pot as the blank since the medium itself also contained $\mathrm{NH}_{3}-\mathrm{N}$ and $\mathrm{PO}_{4}{ }^{3-}$ (Eq. 7-9).

The actual nutrient concentration that leached out due to additional POME and LF in the pots = Conc. leached from POME or LF pot - Conc. leached from tap water pot

Eq. 7

The nutrient concentration absorbed by POME or LF pot $=$ Initial concentration $(0.6 \mathrm{mg} / \mathrm{l})-$ actual concentration that leached out

Eq. 8

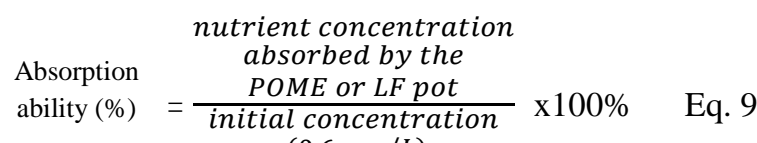
$(0.6 \mathrm{mg} / \mathrm{L})$ 


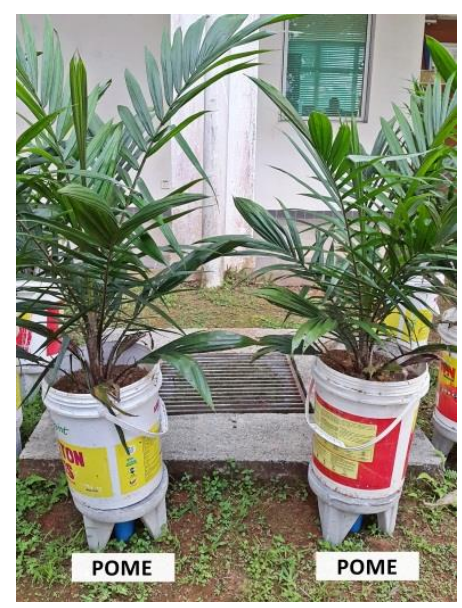

Figure 1. The oil palm seedlings which were watered with POME

\section{One-way ANOVA Analysis}

The $\mathrm{NH}_{3}-\mathrm{N}$ absorption abilities for POME and LF pots were analysed using the IBM SPSS statistics program, One-Way Analysis of Variance (one-way ANOVA). The differences detected in statistical analysis were considered highly significant when $\mathrm{P} \leq 0.05$.

\section{RESULTS \& DISCUSSION}

\section{Soil Analysis}

The soil analyses included color, $\mathrm{pH}$, texture, organic matter and moisture content. The results are shown in Table 1. The soil sample used in this study appeared dark brown in color referring to Munsell Soil-Color Charts, with the $\mathrm{pH}$ value of 4.5 which was considered an acidic type of soil. Based on soil texture analysis, the soil medium was classified as sandy clay which consisted of $40 \%$ clay, $10 \%$ silt and $45 \%$ sand. The soil composition was similar to the soil types that were used in our previous study (Jefferson et al., 2016). However, the soil organic matter (SOM) and moisture content (MC) in this study were only $2.05 \%$ and $2.67 \%$, respectively, which were far lower than in the previous study. The high value of organic matter content in soil can lead to larger pore spaces and thus a higher retention of water in the soil (Roth et al., 1992; Hudson 1994). Hence, the soil that we used in this study contained smaller pore spaces due to a lower SOM value which means that water can be leached out more easily compared to the previous study.

\section{Leachate Study}

The oil palm seedlings were watered with the respective solutions from $17^{\text {th }}$ November 2016 until $28^{\text {th }}$ February 2017. The leachates from the six pots were collected in order to determine the concentration of $\mathrm{NH}_{3}-\mathrm{N}$ and $\mathrm{PO}_{4}{ }^{3-}$ leached out from the pots (Figure 2 and 3 ).

The concentration of $\mathrm{NH}_{3}-\mathrm{N}$ leached out from the pots increased over the study (Figure 2). The average concentration of $\mathrm{NH}_{3}-\mathrm{N}$ that leached out from the pots watered with POME, LF and tap water was $0.45,0.38$ and $0.36 \mathrm{mg} / \mathrm{l}$, respectively. Despite the POME pots showing the highest $\mathrm{NH}_{3}-\mathrm{N}$ leachate concentration over the four months, the rate of $\mathrm{NH}_{3}-\mathrm{N}$ leached out in the POME pots was lower (i.e. $0.0249 \mathrm{mg}^{-1}{ }^{-1}$. week $^{-}$ $\left.{ }^{1}\right)$ than those watered with tap water (i.e. 0.0251 mg. $1^{-1}$. week $^{-1}$ ). This shows that the $\mathrm{NH}_{3}-\mathrm{N}$ contained in the soil can be leached more easily when in its diluted form. This result was also in line with the rate of $\mathrm{NH}_{3}-\mathrm{N}$ leached out in the $\mathrm{LF}$ pot $\left(0.0233 \mathrm{mg} . \mathrm{l}^{-1}\right.$. week $\left.{ }^{-1}\right)$ in which its $\mathrm{NH}_{3}-\mathrm{N}$ concentration was relatively higher than the one in tap water.

On the other hand, adding POME as the watering solution to the pots has increased SOM in the soil medium due to the extremely high concentration of organic matter in POME. The increase of SOM could significantly increase water holding capacity of the soil (Roth et al., 1992; Hudson 1994). Due to this reason, the water holding capacity of the soil in the POME pots was increasing compared to those soils in 
Table 1. Comparison of soil data between our present study and previous paper (Jefferson et al., 2016)

\begin{tabular}{ccc}
\hline Parameter & Present study & $\begin{array}{c}\text { Previous paper from (Jefferson } \boldsymbol{e} \text { t } \\
\text { al. }, \text { 2016) }\end{array}$ \\
\hline Color & Dark brown & Orange \\
pH & 4.5 & N.R. \\
Clay $(\%)$ & 40 & 38 \\
Silt $(\%)$ & 10 & 18 \\
Sand $(\%)$ & 45 & 44 \\
Soil organic matter $(\%)$ & 2.05 & 8.16 \\
Moisture content $(\%)$ & 2.67 & 14.25 \\
Soil class & Sandy clay & Sandy clay \\
\hline
\end{tabular}

N.R. $=$ Not recorded

$\mathrm{LF}$ and tap water pots, hence the rate of $\mathrm{NH}_{3}$ $\mathrm{N}$ leached out from the POME pots was lower than in the tap water only pots. This also explains why the concentration of $\mathrm{NH}_{3}-\mathrm{N}$ in the POME pots were higher than those in the LF and tap water pots because of the lower volume of water leaching out. This finding correlates with the study conducted by Iwara $e t$ al. (2011). The group reported the reuse of POME in agriculture was able to increase the essential nutrients in the soil due to the addition of organic matter that originated from POME. The group also mentioned that the increase of organic matter in the soil can improve the soil structure, water storage and cation exchange capacity of the soil, which supports our study findings.

Similarly to $\mathrm{NH}_{3}-\mathrm{N}$, the pots which were watered with POME also recorded the highest $\mathrm{PO}_{4}{ }^{3-}$ concentration $(1.09 \mathrm{mg} / \mathrm{l})$ leached out, followed by $\mathrm{LF}(0.96 \mathrm{mg} / \mathrm{l})$ and lastly were the pots watered with tap water $(0.66 \mathrm{mg} / \mathrm{l})$. However, the $\mathrm{PO}_{4}{ }^{3-}$ that was leached out from the POME pots showed a decreasing trend compared to those pots watered with LF and tap water over the four-month duration. The negative value in the linear regression trend ($0.0146 \mathrm{mg} . \mathrm{l}^{-1}$. week $^{-1}$ ) for the POME pots showed that more $\mathrm{PO}_{4}{ }^{3-}$ was stored in the soil medium than was released. Again, the pots watered with tap water showed the highest rate of $\mathrm{PO}_{4}^{3-}\left(0.0392 \mathrm{mg}^{3-1}{ }^{-1}\right.$. week $\left.{ }^{-1}\right)$ leached out from the pots. This confirmed that nutrients are more leachable in diluted rather than in concentrated form.
The results from the leachate test showed that the use of POME as a fertilizer at a suitable dosage does not pollute the ground water in terms of nutrient content as it was comparable to the leachates from LF and tap water. Moreover, the nutrients that were introduced into the pots were taken up by the oil palm as well, this further reduces the possibility of polluting the ground water. In addition, our previous study (Jefferson et al., 2016) also found that the sandy clay soil texture has about $77 \% \mathrm{NH}_{3}-\mathrm{N}$ absorption ability which further minimizes the possibility of polluting the ground water. However, it is worth highlighting that over dosage of POME could increase the possibility of negative impacts to the environment.

\section{Nutrient Absorption Ability of POME and LF Pots}

The nutrient absorption abilities of POME and LF pots have been calculated by integrating the nutrient concentrations leached from respective POME and LF pot. The effluent concentrations of respective nutrients from the tap water pot were used as the blank because the medium itself also contains nutrients, and therefore, the nutrients also can be leached out from the pots when raining. Hence, the actual concentration of nutrients leached out from the pots due to the additional POME and LF is represented by subtracting the effluent concentration of tap water pot from the effluent concentration of respective POME or LF pots. Finally, the nutrient absorption ability of each pot can be calculated by subtracting the actual 


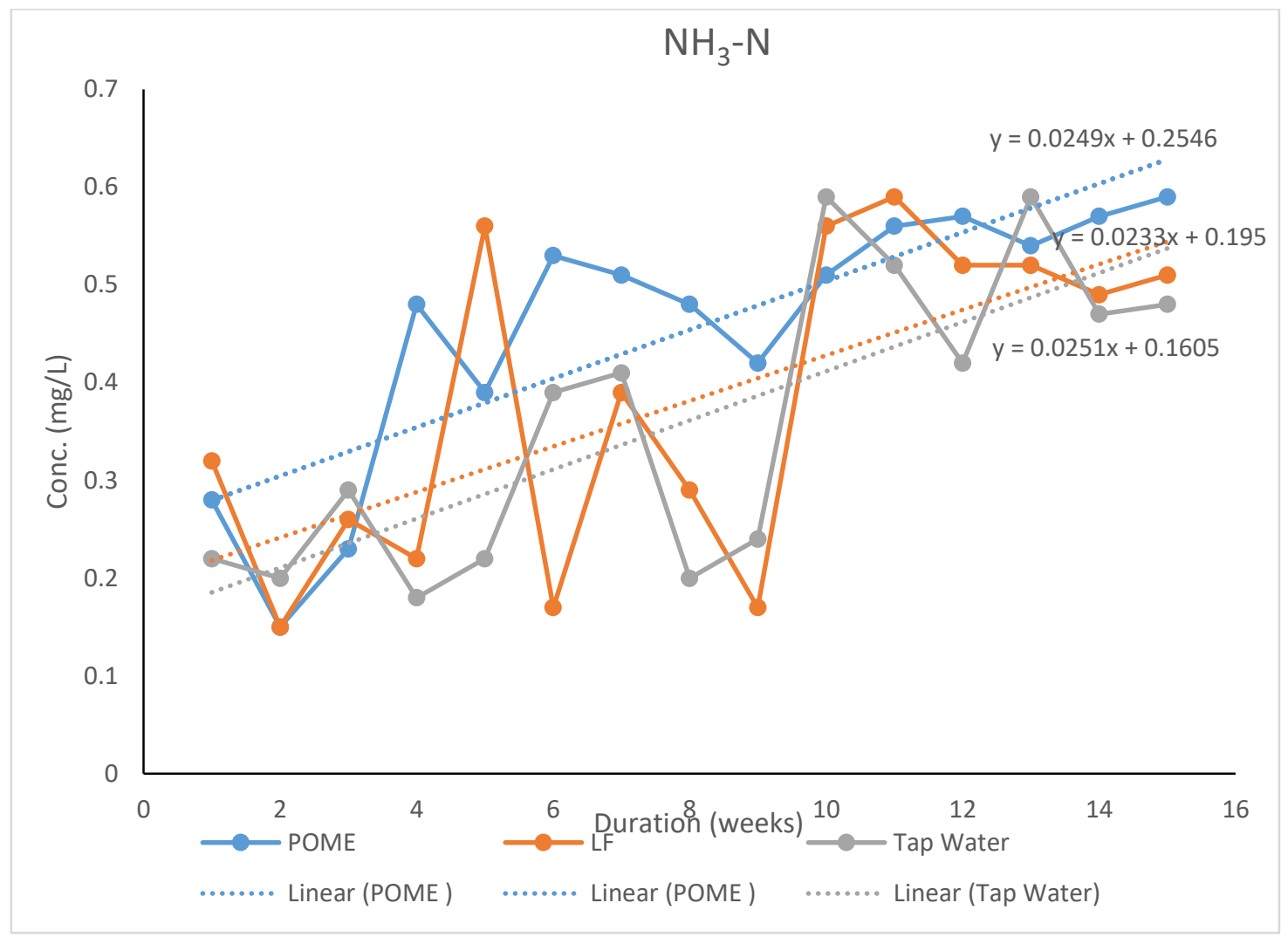

Figure 2. Concentrations of $\mathrm{NH}_{3}-\mathrm{N}$ in the leachates from the pots of POME, $\mathrm{LF}$ and tap water

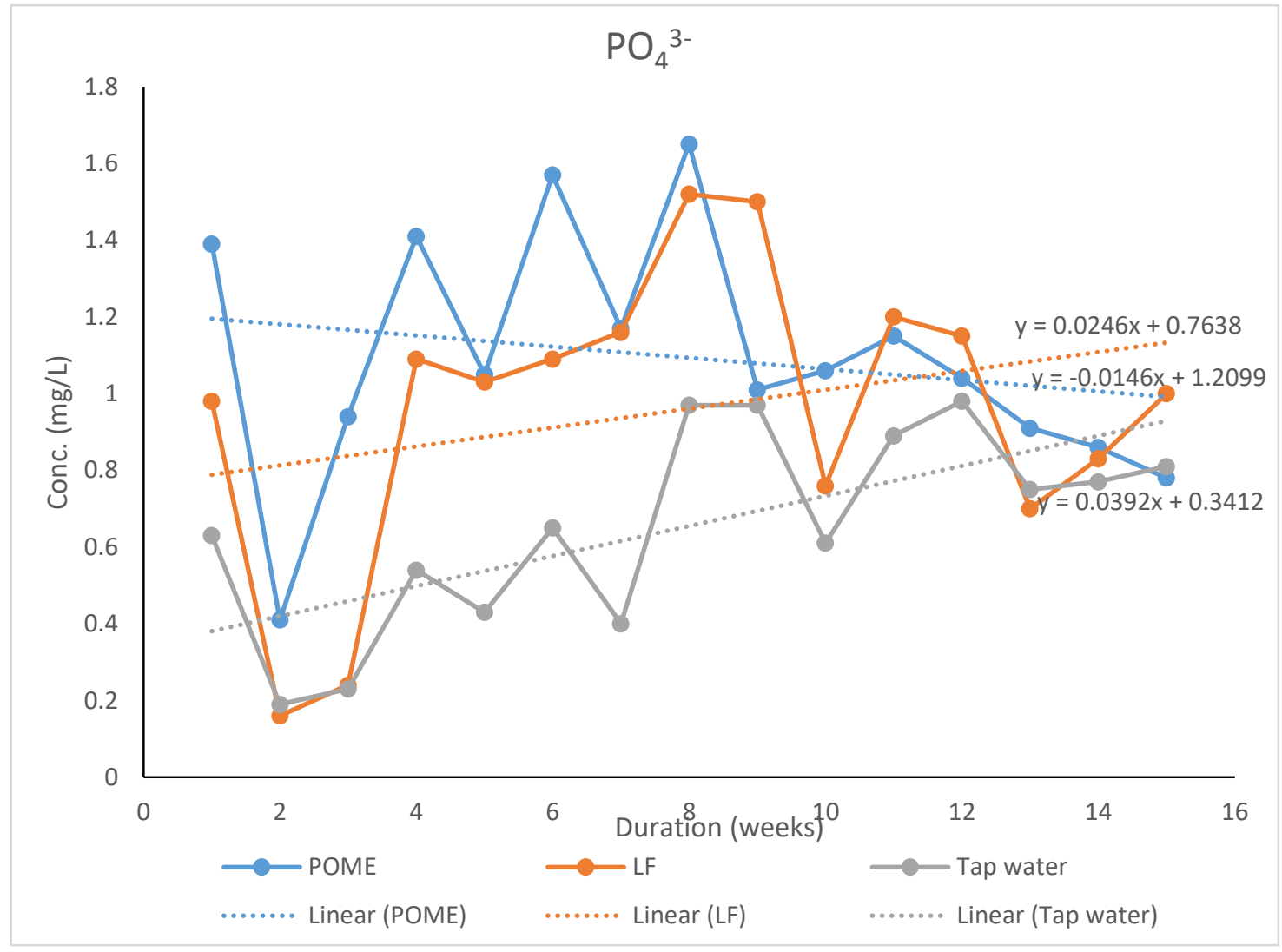

Figure 3. Concentration of $\mathrm{PO}_{4}{ }^{3-}$ in the leachates from the pots of POME, LF and tap water 
concentration from initial concentration (0.6 $\mathrm{mg} / \mathrm{l})$. The mean and standard deviation values of absorption ability in between POME and LF pots are tabulated in Table 2.

The absorption ability of $\mathrm{NH}_{3}-\mathrm{N}$ in the POME pots was higher than the one in LF pots. This is due to the increase of organic matter in the POME pots, which eventually increased the nutrient absorption ability. The report from Iwara et al. (2011) also has stated that the nutrients in the organic fertilizer, especially nitrogen $(\mathrm{N})$, is less leachable compared to inorganic fertilizer. Moreover, the $\mathrm{NH}_{3}-\mathrm{N}$ absorption ability in this study (84\%) was slightly higher than the one in the previous study (77\%) (Jefferson et al., 2016) indicating that the ability was improved after planting oil palm seedling in the medium.

Unfortunately, the comparison of $\mathrm{PO}_{4}{ }^{3-}$ between POME and LF pots was not able to be performed as the initial concentration of $\mathrm{PO}_{4}{ }^{3-}$ in POME was not measured. Nevertheless, the $\mathrm{PO}_{4}{ }^{3-}$ absorption ability in the LF pot was about half that of $\mathrm{NH}_{3}-\mathrm{N}$, revealing that $\mathrm{PO}_{4}{ }^{3-}$ was more leachable compared to $\mathrm{NH}_{3}-\mathrm{N}$. Thus, there is a higher possibility of $\mathrm{PO}_{4}{ }^{3-}$ leaching to the ground water when LF is applied.

\section{One-way ANOVA}

One-way ANOVA for $\mathrm{NH}_{3}-\mathrm{N}$ was performed by using the IBM SPSS software in order to determine the differences of absorption ability between POME and LF. Based on the one-way
ANOVA result, there was no significant difference in the variances of $\mathrm{NH}_{3}-\mathrm{N}$ values between the groups since the $p$-value was 0.305 . This value is more than the $\alpha$ value $(0.05)$. Hence, the absorption ability of $\mathrm{NH}_{3}-\mathrm{N}$ between POME and LF were statistically equal.

\section{Plant Growth Study}

The plant growth study was conducted to compare the growth rate of oil palm seedlings which were watered by three different watering solutions over the four-month period and the results are shown in Figure 4.

All the oil palm seedlings underwent a positive growth over the four-month period. Surprisingly, those seedlings in tap water pots recorded the highest growth rate $(0.56 \mathrm{~cm} /$ day $)$ compared to POME and LF. Meanwhile, the seedlings which were watered by POME recorded the slowest rate $(0.42 \mathrm{~cm} /$ day $)$. This result suggested that the diluted form of nutrients was more well spread and available to be taken up by the oil palm seedlings.

Despite the oil palm seedlings in POME pots recorded the slowest growth rate in this study, but considering the fact that the four-months study period was actually a short period in oil palm plantation, thus for the time being, it still cannot draw a conclusion that POME does not promote the growth of oil palm seedlings. In fact, it can be seen that POME brought a positive growth rate to the oil palm seedlings rather than a negative growth rate.

Table 2. The mean values of absorption ability (\%) of POME and LF pots

\begin{tabular}{cccc}
\hline Fertilizers & & $\mathbf{N H}_{3}-\mathbf{N}$ & PO $_{4}^{\mathbf{3}^{-}}$ \\
\hline POME & Mean (\%) & 84.3 & N.R \\
& $\mathrm{N}$ & 7 & N.R \\
& Std. Deviation (\%) & 21.1 & N.R \\
Liquid & Mean (\%) & 71.9 & 36.2 \\
Fertilizer & $\mathrm{N}$ & 7 & 7 \\
& Std. Deviation (\%) & 14.8 & 49.6 \\
\hline
\end{tabular}

N.R. $=$ Not recorded 


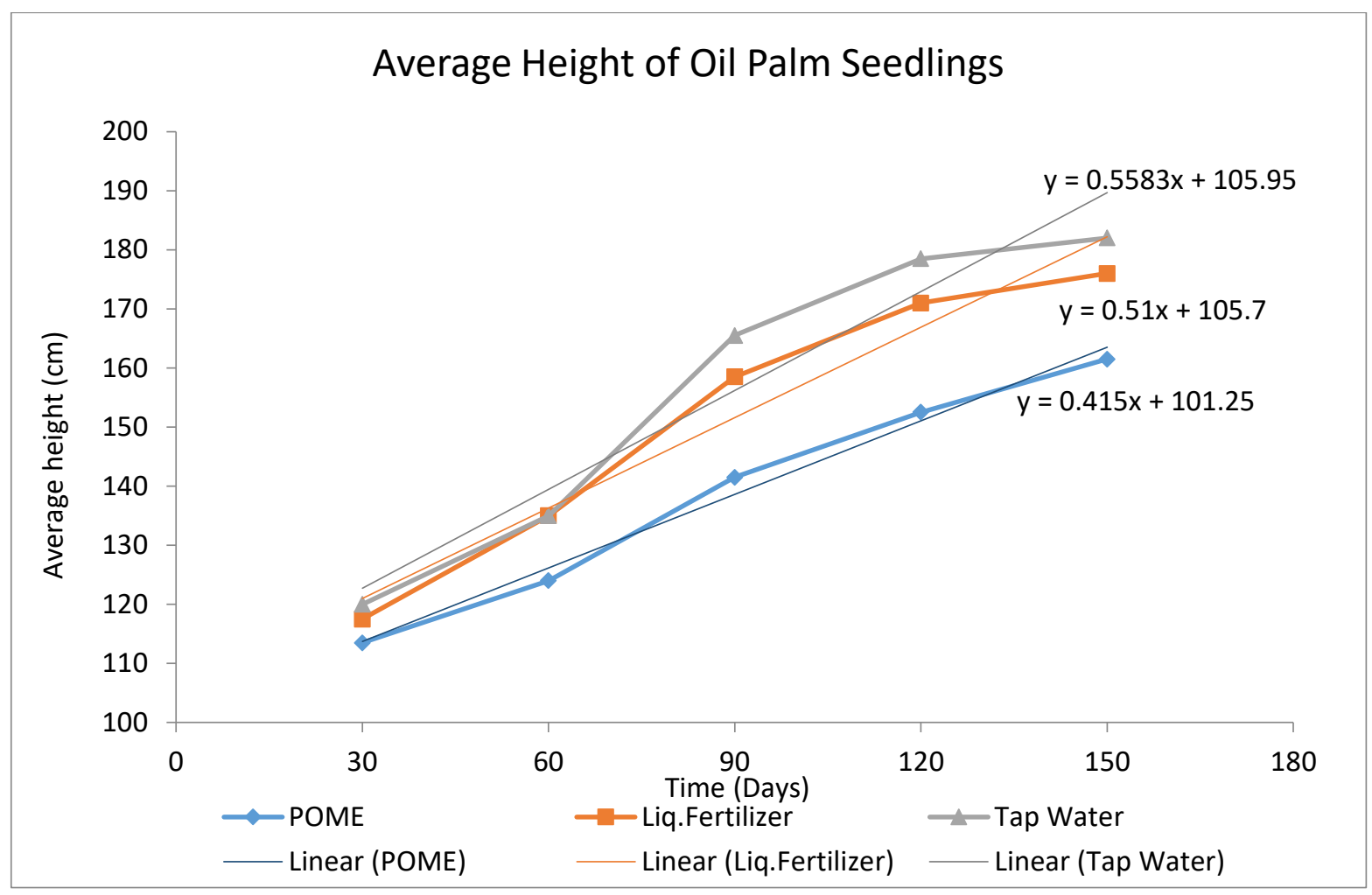

Figure 4. The comparison of the average growth height of oil palm seedlings with different watering solutions

\section{CONCLUSION}

POME has been used as the watering solution in this oil palm growth study. Nutrients were found in the leachates from all the pots which were watered with either POME, LF or tap water. The rates of nutrient leached out from the tap water pot were the highest compared to POME or LF. The $\mathrm{NH}_{3}-\mathrm{N}$ absorption ability in the POME pots were higher than the LF pots due to the increase of organic matter in the POME pots. On the other hand, those oil palm seedlings in the tap water pots recorded the highest growth rate $(0.56 \mathrm{~cm} /$ day $)$, whereas, those in the POME pots had the lowest growth rate $(0.41 \mathrm{~cm} /$ day $)$. In conclusion, the use of POME as an alternative fertilizer at a suitable dosage does not potentially pollute the ground water in terms of its nutrient content since it is comparable to LF based on one-way ANOVA analysis. Moreover, it has been proven to bring positive growth to oil palm seedlings.

\section{ACKNOWLEDGEMENTS}

The authors would like to thank Universiti Malaysia Sarawak for the financial support to the research through MyRA Special Grant Scheme [F07/SpGS/1549/2017]. In addition, the long term research collaboration from Bau Palm Oil Mill Sdn Bhd, SALCRA, Sarawak, is also gratefully acknowledged.

\section{REFERENCES}

Afandi, A.M., Zulkifli, H., Khalid, H., Hasnol, O., Haza, N.Z. \& Zuraidah, Y. (2016). Oil palm fertilizer recommendation for Sabah soil. Oil Palm Bulletin, 72: 1-24.

Ahmad, A.L, Ismail, S. \& Bhatia, S. (2005a). Optimization of coagulation-flocculation process for palm oil mill effluent using response surface methodology. Environmental Science \& Technology, 39: 2828-2834.

Ahmad, A.L, Ismail, S. \& Bhatia, S. (2005b). Membrane treatment for palm oil mill effluent: effect of transmembrane pressure and crossflow velocity. Desalination, 179: 245-255.

Department of Environment (DOE) (1999). Industrial processes and the environment: Crude palm oil industry. Ministry of Natural Resource and Environment, Malaysia. 
Hudson, B.D. (1994). Soil organic matter and available water capacity. Journal of Soil Water Conservation, 49: 189-194.

Iwara, A.I., Ewa, E.E., Ogundele, F.O., Adeyemi, J.A. \& Otu C.A. (2011). Ameliorating effects of palm oil mill effluent on the physical and chemical properties of soil in Ugep, Cross River State, Southern Nigeria. International Journal of Applied Science and Technology, 1: 106-112.

Patel, P. (2015). Zero discharge of palm oil mill effluent through outdoor flash evaporation at standard atmospheric conditions. Oil Palm Bulletin, 71: 14-24.

Jefferson, E.E., Kanakaraju, D. \& Tay, M.G. (2016). Removal efficiency of ammoniacal nitrogen from palm oil mill effluent (POME) by varying soil properties. Journal of Environmental Science and Technology, 9: 111-120.

Liew, W.L., Kassim, M.A., Muda, K.A., LOH, S.K. \& Affam, A.C. (2015). Conventional methods and emerging wastewater polishing technologies for palm oil mill effluent treatment: a review. Journal of Environmental Management, 149: 222-235.

Lim, C.H., Ang, J.J., Lau, S. \& Tay, M.G. (2017). Optimization of hydroxyl radical production using electro-Fenton method for chemical oxygen demand reduction in diluted palm oil mill effluent (POME). Water and Environmental Journal, 31: 578-583.

Loh, S.K., Lai, M.E., Muzzammil, N., Lim, W.S., Choo, Y.M. \& Zhang, Z. (2013). Zero discharge technology of palm oil mill effluent. Journal of Oil Palm Research, 25: 273-281.

Madaki, Y.S. \& Lau, S. (2013) Palm oil mill effluent (POME) from Malaysia palm oil mills: waste or resource. International Journal of Science and Environmental Technology, 2: 1138-1155.
Norulaini, N., Zuhairi, A., Hakimi, M. \& Omar, M (2001). Chemical coagulation of settleable solidfree palm oil mill effluent (POME) for organic load reduction. Journal of Industry Technology, 10: $55-72$.

Nwoko, C.O. \& Ogunyemi, S. (2010). Evaluation of Palm oil mill effluent to maize (Zea mays. L) crop: yields, tissue nutrient content and residual soil chemical properties. Australian Journal of Crop Science, 4: 16-22.

Ogboi, E. \& Izeke, S. (2010). The Influence of POME on soil properties and growth of hot peppers. Fronties, 1: 89-97.

Onyia, C.O., Uyu, A.M., Akunna, J.C., Norulaini, N.A. \& Omar A.K. (2001). Increasing the fertilizer value of palm oil mill sludge: bioaugmentation in nitrification. Water Science and Technology, 44: 157-162.

Roth, C.H., Malicki, M.A. \& Plagge R. (1992). Empirical evaluation of the soil dielectric constant - volumetric water content relationship as the basis of calibration of TDR soil moisture measurements. Journal of Soil Science, 43: 1-13.

Rupani, P.F., Singh, R.P., Ibrahim, M.H. \& Esa, N. (2010). Review of current palm oil mill effluent (POME) treatment methods: vermicomposting as a sustainable practice. World Applied Science Journal, 10: 1190-1201.

United States Department of Agriculture (USDA). Soil Survey Laboratory Methods Manual. Kellogg Soil Survey Laboratory Methods Manual, 2014.

Wu, T.Y., Mohammad, A.W., Jahim, J. \& Anuar, N. (2009). A holistic approach to managing palm oil mill effluent (POME): biotechnological advances in the sustainable reuse of POME. Biotechnology Advances 27: 40-52. 